\title{
Effect of long - term integrated nutrient management on crop yield, nutrition and soil fertility under rice-wheat system
}

\author{
Richa Kumari $^{1}$, Sunil Kumar ${ }^{1}$, Rajkishore Kumar ${ }^{1 *}$, Anupam Das ${ }^{1}$, Ragini Kumari ${ }^{1}$, C. D. \\ Choudhary $^{1}$ and R.P. Sharma ${ }^{2}$ \\ ${ }^{1}$ Department of Soil Science and Agricultural Chemistry, Bihar Agricultural University, Sabour-813210 (Bihar), \\ INDIA [B.A.U. Communication No. 176/2016] \\ ${ }^{2}$ Bihar Agricultural College, Sabour, Bhagalpur-813210 (Bihar), INDIA \\ *Corresponding author. E-mail: kishoreraj1333@gmail.com
}

Received: December 2, 2016; Revised received: March 16, 2017; Accepted: August 23, 2017

\begin{abstract}
Long-term effect of nitrogen substitution (25 to 50\%) through different organics, viz., FYM (farm yard manure), GM (green manure) and WS (wheat straw) on crop yield, nutrition and physico-chemical properties of soil was studied under rice-wheat system. The data of long term experiment revealed that maximum grain yield of 46.83 qha ${ }^{-1}$ in wheat was obtained when $100 \%$ RDF applied through mineral fertilizers after $50 \% \mathrm{~N}$ of RDF being substituted with FYM in rice. Grain yield of wheat declined under control and sub-optimal fertilizer inputs $(50 \%$ or $75 \%$ recommended fertilizer NPK), whereas positive yield increment was observed under treatments receiving organic supplements. The analysis of soil samples showed that soil pH reduced from initial value of 7.40 to 7.22 , organic carbon build-up from $0.46 \%$ to $0.76 \%$, available $\mathrm{N}$ from 194.00 to $225.95 \mathrm{kgha}^{-1}$ available $\mathrm{P}_{2} \mathrm{O}_{5}$ from 23.60 to $49.54 \mathrm{kgha}^{-1}$ and available $\mathrm{K}_{2} \mathrm{O}$ from 155.00 to $189.95 \mathrm{kgha}^{-1}$ However, available Sulphur and DTPA-Zn increased from 7.74 to $14.41 \mathrm{~kg} \mathrm{ha}^{-1}$ and 0.75 to $1.37 \mathrm{mg} \mathrm{kg}^{-1}$ respectively due to long-term (29 years) integrated nutrient management practices under rice-wheat system in alluvial soil. In conclusion, substitution of $50 \%$ and $25 \% \mathrm{~N}$ of RDF to rice through organics either FYM / Green manure / Wheat straw significantly increased the crop yield and nutrient uptake of wheat as well as build up the organic carbon, available $\mathrm{N}, \mathrm{P}_{2} \mathrm{O}_{5}, \mathrm{~K}_{2} \mathrm{O}$, Sulphur, DTPA-extractable $\mathrm{Zn}, \mathrm{Cu}, \mathrm{Fe}$ and Mn of post harvest soil after 29 years of the experiment.
\end{abstract}

Keywords: Chemical fertilizers, Crop yield, Chemical properties, Nutrient uptake, Organics

\section{INTRODUCTION}

After green revolution, scenario of Indian agriculture has faced many problems such as stagnation or even decrease in production and productivity of major crops, deterioration of soil fertility, decline in factor productivity, low diversity of production systems and increasing cost of production. These constraints have cropped-up partially as a result of continuous cropping without proper nutrient management and indiscriminate use of agrochemicals on soil and crops (Sharma and Subehia, 2014). Over the past 40 years, rice-wheat system has seen a phenomenal growth in productivity, and now it is a major cropping system covering about 10 million hectare in the Indo Gangetic plains of India. Stagnation or decline in productivity of rice-wheat system is a result of degradation of the soil and water resources and inefficient nutrient management (Thind et al., 2016). Fertilizers play a vital role in enhancing the production and productivity of any crop, but continuous and imbalanced use of high analysis chemical fertilizers adversely affects the production potential and soil health. Use of chemical fertilizers in combination with organic manure is essential to improve the soil health (Prasad et al., 2010). In integrated use of inorganic and sources of $\mathrm{N}$, repeated applications of organic manures is often recommended to maintain soil fertility and crop productivity (Subehia and Sepehya, 2012). Farm Yard Manure (FYM), Green Manure (GM), crop residue are important and renewable organic sources of nutrients. Large quantities of organic matter are available with the farmers which can be utilized as complementary source to chemical fertilizers.

Long-term field experiments using different agronomic management can provide direct observations of changes in soil quality and fertility and can help in prediction of future soil productivity and soil-environment interactions (Li et al., 2010 and Shen et al., 2010). Increasing productivity and keeping pace with the rising food demand with minimum environmental disturbance has thus become a challenge to farmers and scientists alike. Continuous integrated use of organic manures and fertilizers would be quite promising in assessing the sustainability of crop yield, and plant nutrition visà-vis soil properties. The present investigation was therefore, undertaken to study the long-term effect of integrated nutrient management on crop yield, nutri- 
tion and physicochemical properties of soil under ricewheat system.

\section{MATERIALS AND METHODS}

The present study conducted in 2013 at the Bihar Agricultural College Research Farm $\left(25^{\circ} 23^{\prime} \mathrm{N}, 87^{\circ} 07^{\prime} \mathrm{E}\right.$, 37.19 MSL), Sabour, Bhagalpur, Bihar, India under the network project research program of the Project Directorate on Farming System Research, Modipuram established in 1984. The initial physico-chemical properties of pre-experimental surface $(0-15 \mathrm{~cm})$ soil were: Typic Ustochrept clayey soil; $\mathrm{pH}$ (1:2.5, soil: water) 7.40; electrical conductivity (EC 1:2.5, soil: water) $0.23 \mathrm{dS} \mathrm{m}^{-1}$; organic carbon (Walkley and Black, 1934) $0.46 \%$; available N $194 \mathrm{~kg} / \mathrm{ha}$ (Subbiah and Asija, 1956); $0.5 M$ NaHCO3-extractable Phosphate $23.6 \mathrm{~kg} /$ ha (Olsen et al., 1954) and neutral $1 N$ NH4OAcextractable Potash $155 \mathrm{~kg} / \mathrm{ha}$ (Hanway and Heidel, 1952). The experiment was laid out in randomized block design with 4 replications consisting of 12 treatment combinations viz; control (T1) (no fertilizer no organic manure); $50 \%$ rec-ommended dose of fertilizers (RDF) to both rice and wheat (T2); 50\% RDF to rice and $100 \% \mathrm{RDF}$ to wheat (T3); $75 \% \mathrm{RDF}$ to both rice and wheat (T4); $100 \% \mathrm{RDF}$ to both rice and wheat (T5); $50 \% \mathrm{RDF}+50 \% \mathrm{~N}$ through farm yard manure (FYM) to rice and $100 \%$ RDF to wheat (T6); $75 \%$ $\mathrm{RDF}+25 \% \mathrm{~N}$ through FYM to rice and $75 \% \mathrm{RDF}$ to wheat (T7); $50 \%$ RDF $+50 \% \mathrm{~N}$ through wheat straw to rice and $100 \% \mathrm{RDF}$ to wheat (T8); $75 \% \mathrm{RDF}+25 \%$ $\mathrm{N}$ through wheat straw to rice and $75 \% \mathrm{RDF}$ to wheat (T9); $50 \% \mathrm{RDF}+50 \% \mathrm{~N}$ through green leaf manure (GLM) (Sesbania aculeata) to rice and 100\% RDF to wheat (T10); $75 \% \mathrm{RDF}+25 \% \mathrm{~N}$ through (GLM) to rice and $75 \% \mathrm{RDF}$ to wheat (T11); farmer's fertilizers practice to rice and wheat $(70 \mathrm{~kg} \mathrm{~N}+13.2 \mathrm{~kg} \mathrm{P}+8.3$ $\mathrm{kg} \mathrm{K} / \mathrm{ha})(\mathrm{T} 12)$. The recommended dose of fertilizers (N: P: K) for rice (cv. Sita) and wheat (cv. UP-262) is 80:17.6:33.2 kg/ha and 120:26.4:33.2 kg/ha, respectively. The required amount of FYM, wheat straw and Sesbania was applied 3 weeks before rice transplanting as per treatment to substitute a specified amount of $\mathrm{N}$. The FYM, wheat straw and Sesbania used in this experi-ment contain $0.5,0.65$ and $0.53 \% \mathrm{~N}$, respectively. After completion of $29^{\text {th }}$ cycle (2013) Grain yield and straw yield of wheat were recorded, collected plant and soil samples. Dried plant samples were analysed for total $\mathrm{N}$ content using Kel-Plus analyser (Pelican Equipments, Chennai, Tamilnadu, India). The total $\mathrm{P}$ and $\mathrm{K}$ contents were determined in aqueous extracts prepared after wet-digestion of the organic ma-terial samples in a di-acid mixture of $\mathrm{HNO}_{3}$ and $\mathrm{HClO}_{4}$ as outlined by Page et al. (1982). The N, P and K uptake was calculated from the nutrient concentration in straw, grain and yield data. The post harvest surface soil sample $(0-15 \mathrm{~cm})$ analyzed for different chemical properties viz., organic carbon (Walkley and Black,
1934), available N (Subbiah and Asija, 1956), available $\mathrm{P}_{2} \mathrm{O}_{5}$ (Olsen et al., 1954) and available $\mathrm{K}_{2} \mathrm{O}$ (Hanway and Heidel, 1952). Soil pH (1:2, soil: water) and electrical conductivity (EC 1:2, soil: water) was determined with the method described by Jackson, 1973. Available sulphur was determined by the method given by Chesnin and Yien (1951). Available soil micronutrients were determined following a method described by Lindsay and Norvell (1978) using DTPA extractant.

\section{RESULTS AND DISCUSSION}

Crop yield: The grain and straw yield of wheat (Table 1) varied from a minimum of 7.71 and $11.45 \mathrm{q} \mathrm{ha}^{-1}$ under control $\left(\mathrm{T}_{1}\right)$ to a maximum of 46.83 and $59.44 \mathrm{q}$ $\mathrm{ha}^{-1}$ respectively with the treatment receiving $100 \%$ RDF through chemical fertilizers in wheat after $50 \% \mathrm{~N}$ substitution with FYM in rice $\left(\mathrm{T}_{6}\right)$. Treatments receiving 50\% RDF $+50 \% \mathrm{~N}$ substituted through farm yard manure (FYM), green manure (GM) and wheat straw (WS) enhanced the productivity of wheat grain by $11.47,9.55$ and $6.31 \%$ respectively over $100 \%$ RDF whereas, treatments $\mathrm{T}_{3}, \mathrm{~T}_{7}, \mathrm{~T}_{8} \mathrm{~T}_{9}$ and $\mathrm{T}_{11}$ were at par with $100 \% \operatorname{RDF}\left(\mathrm{T}_{5}\right)$ and rest of the treatments were significantly $(\mathrm{P}<0.01)$ inferior to treatment $\mathrm{T}_{5}$. The omission of chemical fertilizers and organic manures (control treatment) from last 29 years resulted in significantly $(\mathrm{P}<0.01)$ lower yield in comparison to rest of treatments due to continuous mining of nutrients. Further the addition of organic matter also maintains regular supply of macro and micro nutrients in soil, resulting in higher yields. These results are in conformity with the findings of Sharma and Subehia (2014) that maximum wheat grain $\left(36.40 \mathrm{q} \mathrm{ha}^{-1}\right)$ and straw (60.50 $\mathrm{q} \mathrm{ha}^{-1}$ ) yield was obtained with $50 \% \mathrm{~N}$ was substituted through FYM plus 50\% NPK through chemical fertilizers to rice and $100 \%$ NPK through chemical fertilizers to wheat. Urkurkar et al. (2010) reported the integrated use of chemical fertilizers with organic manures viz. FYM, wheat straw or green manure might have added huge quantity of organic matter in soil and thereby producing increased grain and straw yield.

Nitrogen (N) uptake: The uptake of nitrogen (fig. 1) by wheat grain, straw and total uptake increased significantly $(\mathrm{P}<0.01)$ from 11.54 to $70.98,6.32$ to 33.97 and 17.86 to $104.95 \mathrm{~kg} \mathrm{ha}^{-1}$ respectively due to different treatment. FYM, green manuring and straw incorporation to the rice crop have significant impact on total uptake of nitrogen on wheat crop. The effect of FYM and green manuring incorporation were found statistically similar with respect to $\mathrm{N}$ uptake of wheat grain and straw such result was expected due to the fact that organic matter on decomposition resulted in buildup of available $\mathrm{N}$ of soil which accumulated the $\mathrm{N}$ uptake by crops. The beneficial effect of green manure can be related to better availability of nitrogen due to their narrow $\mathrm{C}: \mathrm{N}$ ratio thereby resulting in more 
mineralization of nitrogen. Favorable effects of organics on uptake of nitrogen in rice and wheat crops at Palampur have also been reported by Subehia and Swapana (2012).

Phosphorus (P) uptake: Different treatments have significant effect on $\mathrm{P}$ uptake by wheat grain and straw (fig. 2) indicated that the range of variation in total $\mathrm{P}$ uptake by wheat was from $4.69 \mathrm{~kg}$ ha-1 under control $\left(\mathrm{T}_{1}\right)$ to $28.34 \mathrm{~kg}$ ha- ${ }^{1}$ under $\mathrm{T}_{6}$. Application of chemical fertilizers alone $\left(T_{2}\right.$ to $\left.T_{5}\right)$ or their combined use with organic manures $\left(\mathrm{T}_{6}-\mathrm{T}_{11}\right)$ increased total $\mathrm{P}$ - uptake significantly over control. Application of $100 \%$ RDF in wheat and $50 \% \mathrm{~N}$ substituted through FYM in rice $\left(\mathrm{T}_{6}\right)$ recorded a significant $(\mathrm{P}<0.01)$ increase of 504 per cent over control $\left(\mathrm{T}_{1}\right)$ and treatment $\mathrm{T}_{6}$ was at par with $\mathrm{T}_{5}, \mathrm{~T}_{7}, \mathrm{~T}_{8}, \mathrm{~T}_{9}, \mathrm{~T}_{10}$, and $\mathrm{T}_{11}$. Treatment farmers' practice $\left(\mathrm{T}_{12}\right)$ also recorded an increase of $12.28 \mathrm{~kg}$ ha-

$(275 \%)$ over control. The low phosphorus uptake values under control plots could be due to lower yield as continuous cropping without any external input decreased native phosphorus supply. The higher phosphorus uptake values in organic manures treated plots might be due to the fact that organic materials form chelates with $\mathrm{Al}^{3+}$ and $\mathrm{Fe}^{3+}$ resulting in low phosphorus fixing capacity and thus increasing its availability to plants. The similar results also reported by Thind et al. (2016) at PAU, Ludhiyana that the increase in grain and straw yield of wheat due to application of FYM to previous rice was accompanied by increase in Phosphorus uptake of wheat.

Potassium (K) uptake: The Potassium uptake (Fig. 3) by wheat crop varied from $106.21 \mathrm{~kg} \mathrm{ha}^{-1}$ under $\mathrm{T}_{6}$ to $19.65 \mathrm{~kg}$ ha- ${ }^{1}$ under $\mathrm{T}_{1}$. Application of $100 \% \mathrm{NPK}$ alone $\left(\mathrm{T}_{5}\right)$ registered an increase of $75.65 \mathrm{~kg}$ ha- ${ }^{1}$ over the control which was statistically at par with total $\mathrm{K}$ uptake in $T_{3}, T_{7}, T_{9}$ and $T_{11}$. Among organic manure receiving treatments highest increase was observed under FYM (106.21 kg ha ${ }^{-1}$ ) followed by green manure

Table 1. Long-term effect of Nutrient Management on Crop Yield and nutrient uptake after 29 cropping cycle under ricewheat system.

\begin{tabular}{llllll}
\hline \multirow{2}{*}{ Treatment } & \multicolumn{3}{l}{ Wheat Yield $\left(q \mathbf{q a}^{-1}\right)$} & \multicolumn{3}{l}{ Total uptake $\left(\mathbf{k g h a}^{-\mathbf{1}}\right)$} \\
\cline { 2 - 6 } & Grain & Straw & $\mathbf{N}$ & $\mathbf{P}$ & $\mathbf{K}$ \\
\hline $\mathrm{T}_{1}$ & 7.71 & 11.45 & 17.86 & 4.69 & 19.65 \\
$\mathrm{~T}_{2}$ & 19.28 & 26.59 & 43.67 & 11.44 & 46.32 \\
$\mathrm{~T}_{3}$ & 40.48 & 50.04 & 89.21 & 23.20 & 89.40 \\
$\mathrm{~T}_{4}$ & 30.68 & 40.32 & 68.55 & 17.94 & 71.01 \\
$\mathrm{~T}_{5}$ & 42.01 & 53.57 & 93.95 & 25.13 & 95.30 \\
$\mathrm{~T}_{6}$ & 46.83 & 59.44 & 104.95 & 28.34 & 106.21 \\
$\mathrm{~T}_{7}$ & 43.05 & 55.46 & 96.36 & 25.76 & 98.32 \\
$\mathrm{~T}_{8}$ & 44.66 & 57.67 & 100.26 & 26.93 & 102.52 \\
$\mathrm{~T}_{9}$ & 42.17 & 54.42 & 94.35 & 25.13 & 96.36 \\
$\mathrm{~T}_{10}$ & 46.02 & 58.47 & 103.00 & 27.61 & 104.49 \\
$\mathrm{~T}_{11}$ & 42.89 & 55.10 & 96.07 & 25.53 & 97.71 \\
$\mathrm{~T}_{12}$ & 28.27 & 39.36 & 64.33 & 16.97 & 68.64 \\
$\mathrm{~S} . E m \pm$ & 1.28 & 1.66 & 2.79 & 0.78 & 2.85 \\
$\mathrm{CD}$ & 3.67 & 4.78 & 8.03 & 2.24 & 8.19 \\
$(\mathrm{P}=0.05)$ & & & & & \\
\hline
\end{tabular}

(104.49 $\left.\mathrm{kg} \mathrm{ha}^{-1}\right)$ and wheat straw $\left(102.52 \mathrm{~kg} \mathrm{ha}^{-1}\right)$. Among levels of substitution $50 \% \mathrm{~N}$ substitution through any of the organics recorded higher total $\mathrm{K}$ uptake over $25 \% \mathrm{~N}$ substitution, the differences however, were not significant. The increased uptake of potassium may be ascribed to more availability of potassium from the added fertilizers and manures. Application of manures along with chemical fertilizers recorded highest potassium uptake due to good proliferation of root system, resulting in better absorption of potassium in these plots. Similarly, Prasad et al. (2010) obtained mmaximum $\mathrm{K}$ uptake $89.8 \mathrm{~kg} \mathrm{ha}^{-1}$ of wheat when $50 \% \mathrm{~N}$ was substituted by FYM and remaining through inorganic source under maize-wheat system and minimum in control.

\section{Chemical properties of soil after completion of $29^{\text {th }}$} cycle

Soil pH: Continuous 29 years and combined application of organics and mineral fertilizers have tremendous effects and significantly $(\mathrm{P}<0.01)$ reduced soil $\mathrm{pH}$ (Table 2) up-to7.22 with the treatment T8 - 50\% RDF $+50 \% \mathrm{~N}$ through wheat straw to rice and $100 \% \mathrm{RDF}$ to wheat over $\mathrm{T}_{-1}$ control (7.38) and initial value (7.40) as well as all the treatments where, only mineral fertilizers was applied for both rice and wheat crop. This might be due to release of organic acids after decomposition of organic matters. Yaduwanshi et al. (2013) indicated that soil $\mathrm{pH}$ decreased from the initial level of 8.70 to 8.17 with continuous 12 years use of organic manures combined with the inorganic fertilizer for rice -wheat system at CSSRI, Karnal. Mairan et al. (2005) worked under Long Term Fertilizer Experiment on fixed plot with sorghum-sunflower sequence at Parbhani, indicated significant decrease in $\mathrm{pH}$ values in those treatments where 50 per cent $\mathrm{N}$ was applied through organic source viz., green manure, FYM, press mud compost, wheat straw and at 100 per cent $\mathrm{N}$ through organic sources. Sheeba and Chellamuthu,

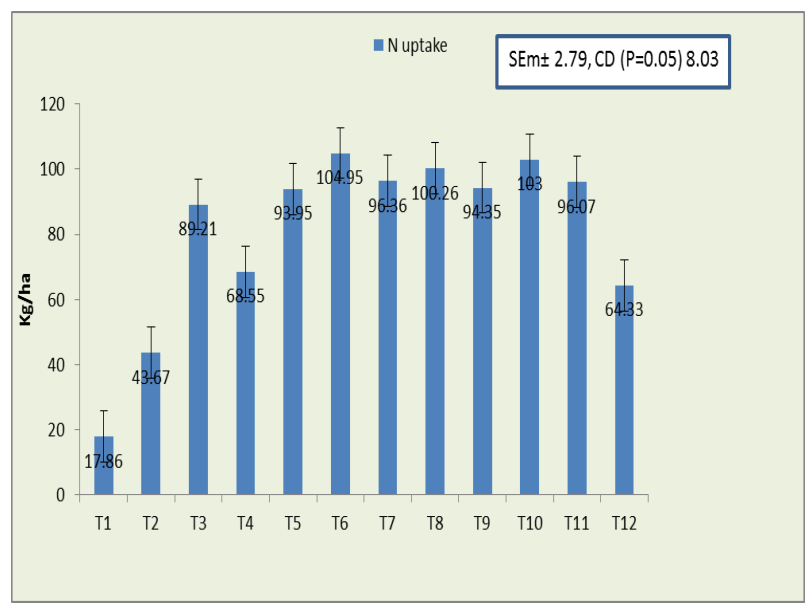

Fig.1. Long-term effect of Nutrient Management on nitrogen uptake $\left(\mathrm{kg} \mathrm{ha}^{-1}\right)$ by wheat crop after 29 cropping cycle under rice-wheat system. 
Richa Kumari et al. / J. Appl. \& Nat. Sci. 9 (3): 1801 - 1807 (2017)

Table 2. Long-term effect of Nutrient Management on chemical properties of soil after 29 cropping cycle under rice-wheat system.

\begin{tabular}{|c|c|c|c|c|c|c|}
\hline Treatment & $\begin{array}{c}\mathrm{pH} \\
(1: 2.5)\end{array}$ & $\begin{array}{c}\text { Organic Carbon } \\
(\%)\end{array}$ & Avail. $\mathbf{N}$ & $\begin{array}{r}\text { Avail. } \mathrm{P}_{2} \mathrm{O}_{5} \\
\left(\mathrm{~kg} \mathrm{ha}^{-1}\right)\end{array}$ & Avail. $K_{2} \mathrm{O}$ & $\begin{array}{l}\text { Avail. S } \\
\left(\mathrm{kg} \mathrm{ha}^{-1}\right)\end{array}$ \\
\hline $\mathrm{T}_{1}$ & 7.38 & 0.34 & 120.10 & & 110.80 & 10.21 \\
\hline $\mathrm{T}_{2}$ & 7.34 & 0.41 & 141.30 & 21.87 & 116.95 & 9.93 \\
\hline $\mathrm{T}_{3}$ & 7.32 & 0.48 & 159.40 & 32.43 & 122.50 & 9.75 \\
\hline $\mathrm{T}_{4}$ & 7.30 & 0.53 & 166.60 & 37.07 & 125.80 & 8.58 \\
\hline $\mathrm{T}_{5}$ & 7.28 & 0.57 & 172.35 & 40.54 & 132.05 & 7.74 \\
\hline $\mathrm{T}_{6}$ & 7.24 & 0.77 & 225.95 & 49.54 & 169.65 & 14.41 \\
\hline $\mathrm{T}_{7}$ & 7.25 & 0.73 & 212.25 & 44.14 & 154.35 & 13.91 \\
\hline $\mathrm{T}_{8}$ & 7.22 & 0.75 & 219.00 & 46.46 & 189.95 & 13.44 \\
\hline $\mathrm{T}_{9}$ & 7.27 & 0.71 & 196.55 & 42.37 & 170.80 & 12.87 \\
\hline $\mathrm{T}_{10}$ & 7.24 & 0.76 & 222.85 & 48.55 & 172.20 & 13.95 \\
\hline $\mathrm{T}_{11}$ & 7.27 & 0.72 & 206.60 & 44.65 & 152.10 & 13.27 \\
\hline $\mathrm{T}_{12}$ & 7.36 & 0.46 & 148.90 & 26.97 & 120.80 & 9.26 \\
\hline S.Em \pm & 0.02 & 0.01 & 2.13 & 0.78 & 1.87 & 1.06 \\
\hline $\mathrm{CD}(\mathrm{P}=0.05)$ & 0.05 & 0.03 & 6.11 & 2.24 & 5.39 & 3.10 \\
\hline Initial (29 year back) & 7.40 & 0.46 & 194.00 & 23.60 & 155.00 & - \\
\hline
\end{tabular}

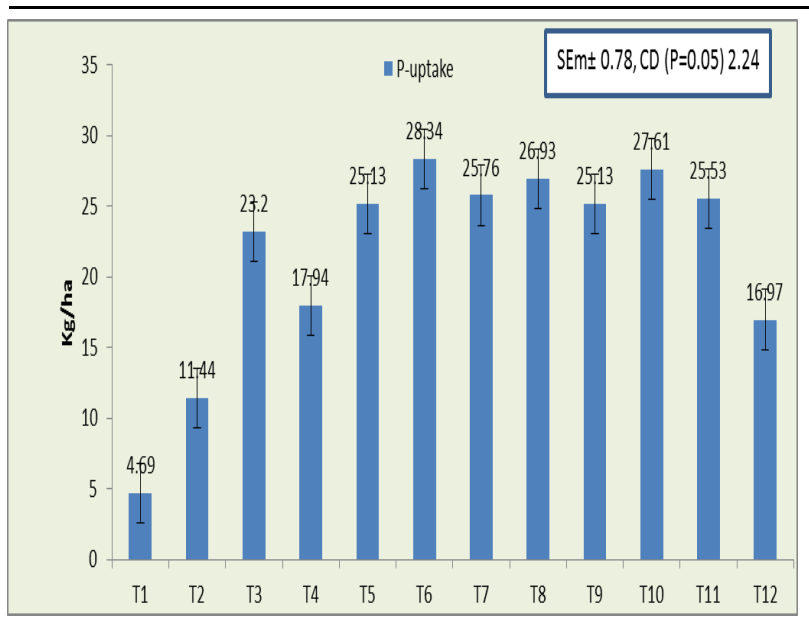

Fig. 2. Long-term effect of Nutrient Management on phosphorus uptake $\left(\mathrm{kg} \mathrm{ha}^{-1}\right)$ by wheat crop after 29 cropping cycle under rice-wheat system.

(2000) observed that the continued application of varying quantities of inorganic fertilizers and their combinations with FYM over 22 years altered the $\mathrm{pH}$ appreciably.

Organic carbon (OC): The organic carbon, one of the crucial factors in sustaining agricultural production, also improved under integrated nutrient management (Table 2). Soil organic carbon varied from $0.34 \%$ under $\mathrm{T}_{1}$ (control) to $0.77 \%$ in the treatment receiving $50 \% \mathrm{RDF}+50 \% \mathrm{~N}$ through FYM during kharif followed by $100 \%$ RDF during rabi $\left(\mathrm{T}_{6}\right)$. Application of organic manures along with chemical fertilizers further increased the organic carbon content of the soil significantly $(\mathrm{P}<0.01)$ over treatment $\mathrm{T}_{5}$ receiving $100 \%$ RDF to both the season. The highest increase of about $126 \%$ over control was observed under $\mathrm{T}_{6}$ followed by $\mathrm{T}_{10}$ and $\mathrm{T}_{8}$ where $50 \% \mathrm{~N}$ was substituted through FYM, GM and WS respectively during kharif every year since 1984. Beneficial effect of integrated use of

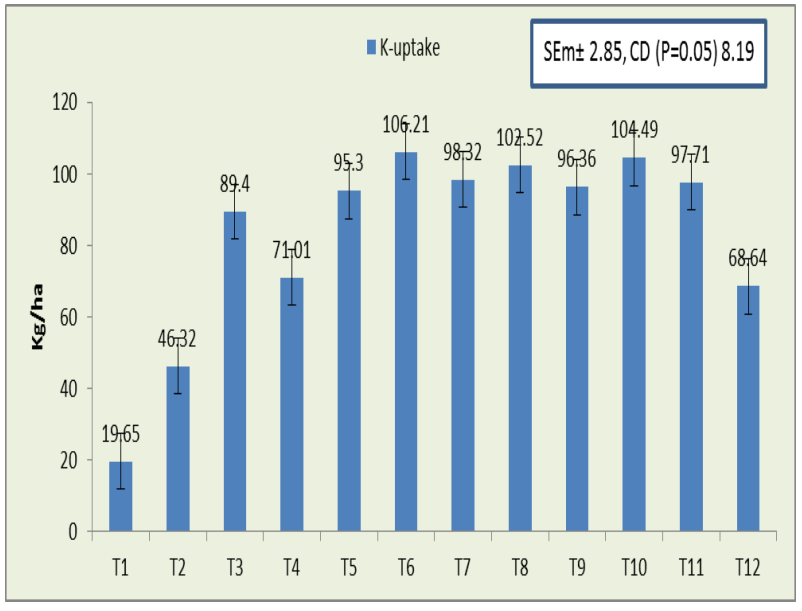

Fig.3. Long-term effect of Nutrient Management on potassium uptake $\left(\mathrm{kg} \mathrm{ha}^{-1}\right)$ by wheat crop after 29 cropping cycle under rice-wheat system.

inorganic fertilizer and organic manures was related to the incorporation of organic material in the soil and increase in number and activity of microorganism and better regulation of organic carbon dynamics in soils. This effect was further enhanced by addition of fertilizers that improved the root and shoot growth. An increase in the soil organic matter leads to an improvement in the nutrient status of the soil. Similarly Yaduwanshi et al. (2013) found that soil organic carbon at the end of 12 years of rice-wheat cropping system was increased by 31.3 and $28.1 \%$ in plots receiving $120-26$ -42 NPK kg ha ${ }^{-1}$ Plus $10 \mathrm{t} \mathrm{ha}^{-1}$ FYM and 120-26-42 NPK kg ha ${ }^{-1}$ Plus $14 \mathrm{t} \mathrm{ha}^{-1} \mathrm{GM}$ which were significantly greater over that receiving only inorganic NPK fertilizer.

Available Nitrogen (N): Continuous manuring and cropping for 29 years significantly decreased available $\mathrm{N}$ content of soil in all the treatments in comparison to its initial status (Table 2) Application of 
Table 3. Long-term effect of Nutrient Management on chemical properties of soil after 29 cropping cycle under ricewheat system.

\begin{tabular}{lllll}
\hline $\begin{array}{l}\text { Treat- } \\
\text { ment }\end{array}$ & $\begin{array}{l}\text { DTPA-Zn } \\
\left(\mathbf{m g ~ k g}^{-1}\right)\end{array}$ & $\begin{array}{l}\text { DTPA-Cu } \\
\left(\mathbf{m g ~ k g}^{-1}\right)\end{array}$ & $\begin{array}{l}\text { DTPA-Fe } \\
\left(\mathbf{m g ~ k g}^{-1}\right)\end{array}$ & $\begin{array}{l}\text { DTPA-Mn } \\
\left(\mathbf{m g ~ k g}^{-1}\right)\end{array}$ \\
\hline $\mathrm{T}_{1}$ & 0.96 & 2.15 & 30.11 & 35.77 \\
$\mathrm{~T}_{2}$ & 0.92 & 2.06 & 29.53 & 34.79 \\
$\mathrm{~T}_{3}$ & 0.85 & 1.99 & 29.23 & 35.35 \\
$\mathrm{~T}_{4}$ & 0.76 & 1.93 & 28.59 & 34.69 \\
$\mathrm{~T}_{5}$ & 0.75 & 1.89 & 28.13 & 34.41 \\
$\mathrm{~T}_{6}$ & 1.37 & 3.51 & 35.48 & 43.19 \\
$\mathrm{~T}_{7}$ & 1.17 & 3.35 & 33.98 & 41.81 \\
$\mathrm{~T}_{8}$ & 1.14 & 3.01 & 33.19 & 40.52 \\
$\mathrm{~T}_{9}$ & 0.99 & 2.91 & 31.66 & 38.56 \\
$\mathrm{~T}_{10}$ & 1.21 & 3.13 & 33.85 & 41.93 \\
$\mathrm{~T}_{11}$ & 1.04 & 2.95 & 32.59 & 38.83 \\
$\mathrm{~T}_{12}$ & 0.78 & 1.94 & 28.54 & 34.67 \\
$\mathrm{~S}$. Em \pm & 0.07 & 0.20 & 2.08 & 2.21 \\
$\mathrm{CD}$ & 0.20 & 0.59 & 6.11 & 6.48 \\
$(\mathrm{P}=0.05)$ & & & & \\
\hline
\end{tabular}

FYM, green manure and wheat straw in kharif along with $100 \%$ NPK in rabi significantly $(\mathrm{P}<0.01)$ increased the available $\mathrm{N}$ content of soil over $100 \%$ NPK $T_{5}$. Higher amount of available N $(225.95 \mathrm{~kg}$ $\mathrm{ha}^{-1}$ ) was recorded in treatment $\mathrm{T}_{6}$ where $50 \% \mathrm{~N}$ substituted through FYM in rice followed by $100 \%$ RDF in wheat. Which, however, exhibited statistical equality with $\mathrm{T}_{10}\left(222.85 \mathrm{~kg} \mathrm{ha}^{-1}\right)$ and $\mathrm{T}_{8}(219 \mathrm{~kg}$ ha$\left.{ }^{1}\right)$ where $50 \% \mathrm{~N}$ substituted through GM \& WS in rice and $100 \%$ RDF in wheat respectively. Application of 50,75 and $100 \%$ RDF to both the crops increased the available $\mathrm{N}$ content by $17.65,38.8$ and 43.5 per cent, respectively over control. Data further showed that substitution of $\mathrm{N}$ at higher rate $(50 \%)$ produced more $\mathrm{N}$ in soil than $25 \%$ substitution. The lower content in control plot is a result of mining of available nitrogen with continuous cropping without fertilization over a long period of time. Increase in available nitrogen with organics is attributed to its direct addition through organics as FYM, wheat straw and green manure enhanced mineralization and build-up of higher available N. Similar results were also found by Kumar and Singh (2010) for rice-wheat system at RAU, Pusa and revealed that application of FYM and green manures along with $100 \%$ NPK significantly $(\mathrm{P}<0.01)$ increased the available $\mathrm{N}$ content of soil over $100 \%$ NPK alone treatment.

Available phosphorus $\left(\mathbf{P}_{\mathbf{2}} \mathbf{O}_{5}\right)$ : A significant $(\mathrm{P}<0.01)$ increase in available $\mathrm{P}_{2} \mathrm{O}_{5}$ (Table-2) was found after $29^{\text {th }}$ cropping cycle in all the organo-inorganic treatments $\left(\mathrm{T}_{6}-\mathrm{T}_{11}\right)$ except $\mathrm{T}_{9}$ over $100 \% \operatorname{RDF}\left(\mathrm{T}_{5}\right)$. The highest available $\mathrm{P}_{2} \mathrm{O}_{5}\left(49.54 \mathrm{~kg} \mathrm{ha}^{-1}\right)$ was accrued under treatment $\mathrm{T}_{6}$ where $100 \% \mathrm{RDF}$ in wheat followed by $50 \% \mathrm{~N}$ substituted with FYM in rice and it is statistically at par with treatment $\mathrm{T}_{10}(48.55)$ and followed by $\mathrm{T}_{8}$ (46.46)14.6\%. However, available $\mathrm{P}_{2} \mathrm{O}_{5}$ content build up to $72 \%$ (40.54 T5) and $91 \%$ (49.54 $\left.\mathrm{kgha}^{-1} \mathrm{~T} 6\right)$ due to continuous 29 years application of $100 \%$ RDF and integration of organic and inorganic fertilizers respectively from the initial values (23.6 $\mathrm{kgha}^{-1}$ ). Buildup of available phosphorus with the application of NPK fertilizers alone or in conjunction with organics might be due to the release of organic acids during decomposition which in turn helped in releasing phosphorus through solubilizing action of native phosphorus in the soil (Gupta et al. 2006 \& Sharma and Sepehya 2014). The organic matter also forms a protective cover on sesquioxides and makes them inactive and thus reduces the phosphate fixing capacity of the soil, which ultimately, helps in release of ample quantity of phosphorus as reported by Urkurkar et al., 2010.

Available potassium $\left(\mathbf{K}_{\mathbf{2}} \mathbf{O}\right)$ : The results in Table 2 revealed that the available $\mathrm{K}_{2} \mathrm{O}$ in soil varied from $110.8 \mathrm{~kg} \mathrm{ha}^{-1}$ under control to $189.95 \mathrm{~kg} \mathrm{ha}^{-1}$ under the treatment receiving $50 \% \mathrm{NPK}+50 \% \mathrm{~N}$ through wheat straw during kharif and 100\% NPK during rabi. Application of organic manures along with chemical fertilizers increased the available $\mathrm{K}_{2} \mathrm{O}$ content of the soil significantly $(\mathrm{P}<0.01)$ over control. The highest increase of about 71.4 per cent available $\mathrm{K}_{2} \mathrm{O}$ content over control and 43.8 percent over $100 \%$ NPK was observed under T8. A significant increase of available $\mathrm{K}_{2} \mathrm{O}$ was accrued $28.4 \%$ in $\mathrm{T}_{6}, 16.8 \%$ in $\mathrm{T}_{7}, 43.8 \%$ in $\mathrm{T}_{8}, 29.3 \%$ in $\mathrm{T}_{9}, 30.4 \%$ in $\mathrm{T}_{10}$ and $15.1 \%$ percent in $\mathrm{T}_{11}$ over $\mathrm{T}_{5}$ $100 \%$ NPK to both rice and wheat. Among organic amended treatments, substitution of $50 \% \mathrm{~N}$ either through FYM, GM or WS to rice is significant over $25 \% \mathrm{~N}$ substitution only in GM \& FYM and shows statistical equality with wheat straw. The possible reason of available $\mathrm{K}_{2} \mathrm{O}$ depression in control and inorganically treated plots might be due to higher potassium mining from the soils. Increase in available potassium due to addition of organic manures may be ascribed to the reduction of $\mathrm{K}$-fixation and release of $\mathrm{K}$ due to interaction of organic matter with clays, besides the direct $\mathrm{K}$ addition to the soil. Sharma and Sepehya (2014). Also obtained the highest increase of about $39.2 \%$ in available $\mathrm{K}\left(167 \mathrm{~kg} \mathrm{ha}^{-1}\right)$ content over control $\left(120 \mathrm{~kg} \mathrm{ha}^{-1}\right)$ was observed where $50 \% \mathrm{~N}$ was substituted through FYM continuously for 20 years plus $50 \%$ NPK through chemical fertilizers to rice and $100 \%$ NPK through chemical fertilizers to wheat under rice wheat system.

Available sulphur (S): The available $\mathrm{S}$ content of soil was significantly $(\mathrm{P}<0.01)$ influenced by application of different treatments (Table-2). Range of Sulphur varied from a minimum of $7.74 \mathrm{~kg} \mathrm{ha}^{-1}$ in treatment receiving $100 \%$ RD of NPK $\left(T_{5}\right)$ to a maximum of 14.41 $\mathrm{kg} \mathrm{ha}^{-1}$ in $\mathrm{T}_{6}(100 \% \mathrm{RDF}$ in wheat after $50 \% \mathrm{~N}$ substitution with FYM in rice). Application of organic amendments induced positive effect on the availability of sulphur. A significant increase in available Sulphur was resulted in treatments receiving $50 \% \mathrm{~N}$ through FYM (14.41 kg ha- ${ }^{1}$ ) followed by $50 \% \mathrm{~N}$ through green manuring $\left(13.95 \mathrm{~kg} \mathrm{ha}^{-1}\right)$ and $50 \% \mathrm{~N}$ substituted 
with wheat straw (13.44 $\left.\mathrm{kg} \mathrm{ha-}{ }^{1}\right)$ than $100 \%$ RDF through inorganic fertilizer. Low sulphur content in $\mathrm{T}_{5}$ could be due to no addition of sulphur and its removal by crops and secondly because of low organic content in these treatments as Sulphur is known to be an integral part of soil organic matter. Sharma and Subehia (2014) reported that application of chemical fertilizers in combination with organic manures increased in available Sulphur content of the soil over control. Addition of FYM, green manure and wheat straw contributed an appreciable amount of Sulphur i. e. 0.17, 0.08, $0.06 \%$, respectively, adding about $6.0,1.12$ and $3.6 \mathrm{~kg}$ $\mathrm{ha}^{-1}$ to the soil at $50 \%$ substitution rate which resulted in increased sulphur content of the soil over control.

Micronutrient: The available micronutrients (Table 3) $\mathrm{Zn}, \mathrm{Cu}, \mathrm{Fe}$ and $\mathrm{Mn}$ content in the post harvest soil after wheat crop of $29^{\text {th }}$ rotations as influenced by different treatments and varied from 0.75 to $1.37,1.89$ to $3.09,28.13$ to 36.67 and 34.41 to $43.19 \mathrm{mg} \mathrm{kg}^{-1}$ soil, respectively. The significantly $(\mathrm{P}<0.01)$ and highest DTPA- Zn (1.37 mg kg-1), Cu (3.09 mg kg-1), Fe (36.67 mg kg$\left.{ }^{-1}\right)$ and $\mathrm{Mn}\left(43.19 \mathrm{mg} \mathrm{kg}^{-1}\right)$ were recorded with the application of $50 \%$ mineral NPK fertilizer supplemented with $50 \% \mathrm{~N}$ through FYM to rice and $100 \%$ RDF to wheat $\left(\mathrm{T}_{6}\right)$ as compare to recommended level of NPK fertilizer $\left(T_{5}\right)$. Treatments $T_{1}, T_{2}, T_{3}, T_{4}$ and $\mathrm{T}_{12}$ were at par with $100 \% \operatorname{RDF}\left(\mathrm{T}_{5}\right)$ in the respect of DTPA- $\mathrm{Zn}$ and $\mathrm{Cu}$, while treatments $\mathrm{T}_{1}, \mathrm{~T}_{2}, \mathrm{~T}_{3}, \mathrm{~T}_{4}$, $\mathrm{T}_{9}, \mathrm{~T}_{11}$ and $\mathrm{T}_{12}$ were found statistically similar to $\mathrm{T}_{5}$ for DTPA-Fe and Mn. The results were also revealed that use of FYM, wheat straw and green manure along with chemical fertilizers significantly $(\mathrm{P}<0.01)$ superior over alone and/or recommended dose of chemical fertilizers application. However, there has been not significant but considerable depletion in available micronutrient status of post harvest soil were observed under only mineral nutrient applied treatments $\left(\mathrm{T}_{2}, \mathrm{~T}_{3}\right.$, $\mathrm{T}_{4}$ and $\left.\mathrm{T}_{5}\right)$ as compare to treatment control $\left(\mathrm{T}_{1}\right)$ where no any nutrient applied for both cereal crops. It might be due to continuous use of only NPK chemical fertilizers and mining of these micronutrients due to long term intensive cultivation of cereal-cereal cropping sequence under the lack of addition of any organic manure or crop residues which further suggest the necessity of regular use of organics for maintain micronutrient status of soils as well as Integrated nutrient management useful in maintaining available micronutrient status of soil over a long term cropping period. Addition of organic materials might have enhanced the microbial activity in the soil and consequently the release of complex organic substances like chelating agents could have prevented micronutrients from precipitation, fixation, oxidation and leaching and also addition of these nutrients through organic sources. Subehia and Sepehya (2012) observed that the amount of available $\mathrm{Fe}, \mathrm{Mn}, \mathrm{Cu}$ and $\mathrm{Zn}(61.80,41.18,2.64$ and $0.98 \mathrm{mg} \mathrm{kg}^{-1}$, respectively) was maximum where $50 \%$
$\mathrm{NPK}+50 \% \mathrm{~N}$ through FYM in karif and 100\% NPK in rabi had been applied followed by $75 \%$ NPK $+25 \%$ $\mathrm{N}$ through FYM in karif and $75 \%$ NPK in rabi which were significantly higher over control. Kharche et al. (2013). Also found considerable depletion in available $\mathrm{Fe}, \mathrm{Mn}, \mathrm{Cu}$ and $\mathrm{Zn}$ status of soil as compared to their initial status before 22 years under only chemical fertilizers. However, integration of organics maintained the level of micronutrient cations above the critical level in soil. The continuous use of only chemical fertilizers caused considerable depletion of all the four micronutrient cations which indicates mining of these nutrients due to long term intensive cultivation of cereal-cereal cropping sequence under the lack of addition of any organic manure or crop residues which further suggests the necessity of regular use of organics for maintaining micronutrient status of soils.

\section{Conclusion}

After 29 years long term experiment results, it could be concluded that Substitution of $50 \% \mathrm{~N}$ through FYM or WS or GM in rice followed by $100 \%$ RDF in wheat proved to be efficient nutrient management options for crop production and nutrition, increasing soil organic carbon, available $\mathrm{N}, \mathrm{P}, \mathrm{K}, \mathrm{S}$ and micronutrient over all the mineral fertilizer treatments as well as control after $29^{\text {th }}$ cropping cycle. With the partial substitution of $25 \% \mathrm{~N}$ through FYM or GM or WS in rice and $75 \%$ $\mathrm{RDF}$ in wheat gives higher or almost similar yield than 100\% RDF (NPK 120:26.4:33.2 kg/ha). Thus 25\% inorganic fertilizer can be saved.

\section{REFERENCES}

Chesnin, L. and Yien, C.H. (1951). Turbidimetric determination of available sulphates. Soil Science Society of America Proceedings, 15:149-151

Gupta, V., Sharma, R. S. and Vishvakarma, S. K. (2006). Long-term effect of integrated nutrient management on yield sustainability and soil fertility of rice (Oryza sativa)-wheat (Triticum aestivum) cropping system. Indian Journal of Agronomy, 51(3): 160-164

Hanway, J.J. and Heidel, H. (1952). Soil analysis methods as used in Iowa state college, Soil Testing Laboratory. Iowa Agriculture, 54: 1-31

Jackson, M.L. (1973) Soil Chemical Analysis. Printice Hall of India Pvt. Ltd., New Delhi

Kharche, V.K., Patil, S.R., Kulkarni, A. A., Patil, V.S. and Katkar, R. N. (2013) Long-term integrated nutrient management for enhancing soil quality and crop productivity under intensive cropping system on vertisols. Journal of the Indian Society of Soil Science. 61 (4): 323-332

Kumar, V. and Singh. A. P. (2010). Long term effect of green manuring and farm yard manure on yield and soil fertility status in rice-wheat cropping system. Journal of the Indian Society of Soil Science. 58(4): 409-412

Li, B.Y., Huang, S.M., Wei, M.B., Zhang, H. and Shen, Al. (2010) Dynamics of soil and grain micronutrients as affected by long-term fertilization in an aquic Inceptisol. Pedosphere 20: 725-735 
Lindsay, W.L. and Norvell, W.A. (1978). Development of a DTPA soil test for zinc, iron, manganese and copper. Soil Science Society American Journal. 42: 421-448

Mairan, N. R., Patil, S. G. and Kachhave, K. G. (2005). Physico-chemical properties under sorghum-sunflower cropping sequence in Vertisols. J. Soils Crops, 15(2): 352-355

Olsen, S.R., Cole, C.V., Watanbe, F.S. and Dean, L.A. (1954). Estimation of available phosphorous in soil by extraction with sodium bicarbonate. United States Department of Agriculture circular no. 939

Page, A.L., Miller, R.H., Keeney, D.R. (1982). Methods of Soil Analysis, Part 2 - Chemical and Microbiological Properties. Agronomy, No. 9. $2^{\text {nd }}$ Edition. American Society of Agronomy, Soil Science Society of America Publishing, Madison

Prasad, J., Karmakar, S., Kumar, R. and Mishra, B. (2010). Influence of integrated nutrient management on yield and soil properties in maize-wheat cropping system in an alfisol of Jharkhand. Journal of the Indian Society of Soil Science, 58(2): 200-204

Sharma, Upinder and Subehia, S.K. (2014) Effect of LongTerm Integrated Nutrient Management on Rice (Oryza sativa L.)- Wheat (Triticum aestivum L.) Productivity and Soil Properties in North-Western Himalaya. Journal of the Indian Society of Soil science, 62:248-254

Sheeba, S. and Chellamuthu, S. (2000). Effects of long-term application of fertilisers and manures on soil properties and yield under maize-cowpea-ragi rotation. J. Eco. Physiology. 3:117-121

Shen, J.P., Zhang, L.M., Guo, J.F., Ray, J.L. and He, J.Z. (2010). Impact of long-term fertilization practices on the abundance and composition of soil bacterial communities in Northeast China. Applied Soil Ecology, 46:119-124

Subbiah, B. V. and Asija, G. L. (1956). A rapid procedure for estimation of available nitrogen in soils. Current Science. 25: 259-260

Subehia, S.K. and Sepehya, S. (2012) Influence of LongTerm Integrated Nitrogen substitution through organics on yield, uptake and available nutrients in rice wheat system in acid soil. Journal of the Indian Society of Soil science 60:213-217

Thind, H. S., Sharma S., Singh V., Sran, H.S., Singh V. and Singh Y. (2016) Integration of Fertilizer Nitrogen, Farmyard Manure and Multi-strain Microorganisms for sustainable production of Rice-Wheat system. Journal of the Indian Society of Soil Science 64:78-85

Urkurkar, J.S., Tiwari, A., Chitale, S. and Bajpai, R.K. (2010). Influence of long term use of inorganic and organic manures on soil fertility and sustainable productivity of rice (Oryza sativa) and wheat (Triticum aestivum) in Inceptisols. Indian Journal of Agricultural Sciences, 80(3): 208-212

Walkley, A. and Black, C.A. (1934). An examination of wet acid method for determining soil organic matter and a proposed modification of the chromic acid titration method. Soil Science. 37: 29-38

Yaduwanshi, N.P.S., Sharma D. R. and Swarup A. (2013) Impact of integrated nutrient management on soil properties and yield of rice and wheat in a longterm experiment on a reclaimed sodic soil. Journal of the Indian Society of Soil Science. 61(3):188-194 